\title{
Anatomy and lignification status of the Lophanthera lactescens Ducke plant grown in vitro
}

\author{
Amaral, D. ${ }^{a}$, Abreu, HS. ${ }^{a *}$, Lima, HRP. ${ }^{b}$, Gevú, KV ${ }^{b}$, Elias, $T F^{a}{ }^{a}$ and Tenório, J. ${ }^{a}$

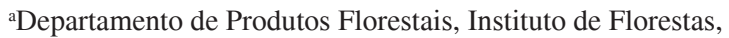 \\ Universidade Federal Rural do Rio de Janeiro - UFRRJ, BR 465, Km 7, CEP 23890-000, Seropédica, RJ, Brazil \\ ${ }^{\text {b}}$ Departamento de Botânica, Instituto de Biologia, Universidade Federal Rural do Rio de Janeiro - UFRRJ, BR 465, Km 7 , \\ CEP 23890-000, Seropédica, RJ, Brazil \\ *e-mail: abreu@ufrrj.br
}

Received March 22, 2011 - Accepted July 4, 2011 - Distributed May 31, 2012

(With 3 figures)

\begin{abstract}
This aim of this study was to evaluate the lignification in young stems of the Lophanthera lactescens Ducke plant grown in vitro L. lactescens (Malpighiaceae), a species endemic in the Brazilian Amazon that possesses both medicinal properties and could be used in the forest product industry. Plants grown in vitro condition in MS medium were analyzed using Infrared (IR) microspectroscopy in a diffuse reflectance mode, fluorescence microscopy. Moreover, histochemical tests such as the Wiesner and Maüle test were run to monitor the process of lignification in cell walls. The spectra of IR microscopy recorded using cross section tissue are representative of guaiacyl/syringyl lignin, based on the 1336 and $1246 \mathrm{~cm}^{-1}$ signal. Individuals presenting stem sprains, resulting from the marked development, produced gelatinous fibers with a clear cellulose layer. Initially, fluorescence microscopy demonstrated lignin deposition in the cell corner region having progressive deposition in the secondary wall of tracheary elements of the stem.
\end{abstract}

Keywords: lignification, fluorescence, infrared microspectroscopy.

\section{Anatomia e status da lignificação de plantas de Lophanthera lactescens Ducke crescidas in vitro}

\begin{abstract}
Resumo
Esta pesquisa teve como objetivo avaliar a lignificação em caules jovens de plantas de Lophanthera lactescens Ducke crescidas in vitro. L. lactescens (Malpighiaceae) é uma espécie endêmica da Amazônia Brasileira que, além de propriedades medicinais, apresenta potencial para a indústria de produtos florestais. As plantas foram crescidas in vitro, usando-se meio nutritivo MS. As análises foram realizadas por microespectrometria no infravermelho, no modo reflectância difusa. Microscopia com fluorescência e testes histoquímicos de Wiesner e Maüle foram realizados para o acompanhamento do processo de lignificação. Os espectros registrados a partir da microscopia no infravermelho mostraram sinais em 1336 e $1246 \mathrm{~cm}^{-1}$, característicos de ligninas siringílica e guaiacílica. Indivíduos que apresentaram entorses no caule, em decorrência do acentuado desenvolvimento, produziram fibras gelatinosas, com a camada de celulose evidente. A microscopia com fluorescência evidenciou deposição de lignina inicialmente nos ângulos das células, com depósito progressivo ocorrendo na parede secundária dos elementos traqueais do caule.
\end{abstract}

Palavras-chave: lignificação, fluorescência, microscopia infravermelho.

\section{Introduction}

This article deals with the study of lignification of the Lophanthera lactescens Ducke species, (Malpighiaceae family), native to the Brazilian Amazon. Commonly known as 'lanterneira' or 'gold chain tree', it has a straight trunk, a diameter ranging from 30 to $40 \mathrm{~cm}$, and can grow to a height of $20 \mathrm{~m}$ (Paoli, 1997).

The species has a prominent position amongst the Brazilian forest biodiversity due to its potential as lumber and for pharmaceutical use (Abreu et al., 1990). The

wood of this tree is moderately heavy, compact, has high natural durability, resistance and hardness (Trevisan, 2003). Lophanthera lactescens is commonly adopted in the heavy construction industry such as: beams, ceilings, rafters and is used for cabinetwork and carpentry (Corrêa, 1926; Lorenzi, 1992).

The process of lignification has been the subject of various scientific articles (Monties, 1989; Donaldson, 2001; Martone et al., 2009), identified as a fundamental 
building block in the evolutionary process of plants and land colonization. Plants have adapted to natural adversities, developing a vertical growth antagonizing gravity; structural resistance for water conduction; plague and disease resistance, etc. In this context, lignin has emerged, which is a remarkable substance with a threedimensional molecular structure formed by three basic units of phenylpropanoids: p-coumaryl alcohol, guaiacyl alcohol and sinapyl alcohol. This polymer binds to a multimolecular complex arranged by cellulose, hemicellulose and structural protein, each connected by cross-linking with other cell wall components (Abreu et al., 2009). This compound has generated interest in Science and Economy for over 150 years (Saliba et al., 2001). It has been detected in higher quantities in the secondary wall of fibers, vessels and tracheids, providing mechanical support and rigidity. It occurs, in a smaller amount, in the periderm, associated to suberin and acting as a barrier against pathogens (Browning, 1967; Guimarães et al., 2003).

Lignification takes place in a latter differentiation stage of xylem cells, where lignin is deposited within the carbohydrate matrix of the cell wall, filling intercellular spaces. It begins in cell corners, in middle lamella and in S-layers, and continues towards the lumen (Donaldson, 2001). It is variable among species, tissues, development stage and cell location. Several methodologies have been applied in lignification studies (Terashima and Fukushima, 1988; Donaldson, 2001; De Micco and Aronne, 2007). The use of biotechnological tools has brought about new findings, especially those defining the in loco lignin formation (Morais et al., 2005). The in vitro growth technique using culture media for germination allows for the physiological and nutritional effects of growth regulators and other chemical constituents related to the monolignol formation process in plants (Souza and Abreu, 2007). The objective of this research was to identify the lignification process in the roots and the stem of Lophanthera lactescens grown in vitro, using a modern technique of infrared microscopy and fluorescence supported by anatomy analyses to be a woody plant for lignification study.

\section{Material and Methods}

The seeds for in vitro plant development of L. lactescens

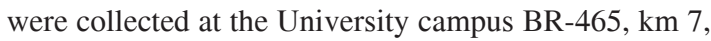
Seropédica - RJ ( $22^{\circ} 46^{\prime}$ latitude and $43^{\circ} 41^{\prime}$ longitude). The species was identified and registered as $n^{\circ}$ (RBR 34066), located in the Herbarium of the Botany Department of Biology. The experiments were performed in two different laboratories, the Wood Biotechnology Laboratory, Department of Forest Products, Forestry Institute and the Plant Anatomy Laboratory, Department of Botany, both located at the Universidade Federal Rural do Rio de Janeiro.

\subsection{In vitro germination of Lophanthera lactescens Ducke seeds}

Lophanthera lactescens seeds were disinfected using a solution comprised of $2.5 \%$ sodium hypochlorite $+0.2 \mathrm{~mL} . \mathrm{L}^{-1}$ of Tween 20 and $1 \%$ hydrogen peroxide, and then inoculated in MS medium (Murashige and Skoog, 1962), containing 30 g.L. $\mathrm{L}^{-1}$ of sucrose and $7 \mathrm{~g}$ of Agar $\left(\right.$ Vetec $\left.^{\circledR}\right)$. The $\mathrm{pH}$ was adjusted to 5.7 and medium sterilization was performed in an autoclave at $121^{\circ} \mathrm{C}, 1 \mathrm{~atm}$, for 30 minutes. Transparent glass flasks $(6 \times 10 \mathrm{~cm})$ with translucent covers were used, containing $50 \mathrm{~mL}$ of culture medium, distributed from 5 to 7 seeds per flask, totaling 30 flasks. For the monitoring of plant lignification, the containers were kept in a germination chamber at a photoperiod of 16 hours at $25 \pm 1{ }^{\circ} \mathrm{C}$ and $\mathrm{RH} 62 \%$ over a 9 to 20 month period. For the anatomy study, three samples of the individuals per container were used.

\subsection{Bright field and fluorescence microscopy}

To evaluate anatomical structure and monitor the lignification process, cross-sections of the young stem were performed, from $1^{\text {st }}$ to $8^{\text {th }}$ internodes and of adventitious roots (2-17.5 $\mathrm{cm}$ from the root cap) of individuals aged between 9 and 20 months. The plants measured between 8 and $12 \mathrm{~cm}$, had 5 to 8 internodes, bright green stems, slightly striated, rectilinear and twisted when the plant exceeded the container's capacity; opposite simple leaves, with stipules at the base. The analyzed root samples presented 14 to $17.5 \mathrm{~cm}$ in length having a diameter of approximately $1 \mathrm{~mm}$. Generally, the roots were white in color, very thin and in some areas above the apical region showed a thickened part followed by a narrowing. With the development of the roots, there was winding across the container and a change in color to brown. Since the study was conducted in plants, as they had an advanced stage of development (from nine months of age), it was not possible to define the primary root.

Stems and roots were sectioned using a Ranvier microtome for the preparation of semi-permanent slides. The sections were clarified with $50 \%$ sodium hypochlorite, neutralized in $1 \%$ acetic water, washed in distilled water, and stained with a solution of $2 \%$ astra blue and $0.5 \%$ safranin diluted in water (Bukatsch, 1972).

In the preparation of permanent slides, the stem and root sections were placed directly in 30\% alcohol, following an alcoholic series and absolute alcohol, and embedded in Leica Historesin (Gerrits and Smid, 1983). Cross-sections of $3 \mu \mathrm{m}$ were obtained using a rotating microtome, which were then stained with $0.05 \%$ toluidine blue (O'Brien et al., 1981).

Photomicrographs were recorded using an Olympus BX 51epifluorescence microscope, attached to a computer equipped with Cell Imaging, an image processing system.

\subsection{Histochemical tests}

For histochemical tests, cross-sections were obtained from fresh material using a Ranvier microtome. The purpose was to detect: starch using a Lugol iodine solution (Berlyn and Miksche, 1976); lignin using the Wiesner test (Lin and Dence, 1992); lignin type guaiacyl (brown color) and syringyl (red color) using the Maüle test (Lin and Dence, 1992). The latter was modified to prevent cell rupture, using $50 \%$ diluted $\mathrm{NH}_{4} \mathrm{OH}$ for 15 seconds. The nature of 
calcium oxalate crystals was observed by dissolution with hydrochloric acid (Chamberlain, 1932) and by observation under polarized light. Lipidic substances were also observed using Sudan IV (Jensen, 1962) and phenolic substances using potassium dichromate (Gabe, 1968).

\subsection{Infrared spectroscopy (solid state)}

Powdered samples of roots formerly extracted with ciclohexane, ethyl acetate and methanol (free of extractive) were grounded in the ball mill for 12 hours. These samples were then lyophilized (TERRONI - Model ENTERPRISE apparatus) for 12 hours. $2 \mathrm{mg}$ samples were added to $200 \mathrm{mg}$ of $\mathrm{KBr}$. Infrared spectra were registered in a VARIAN 640-IR FT-IR spectrometer. The spectra were registered in the range of $700-4000 \mathrm{~cm}^{-1}$, spectral resolution of $4 \mathrm{~cm}^{-1}$, and 128-scan.

\subsection{Infrared microscopy}

Cross-sections of stems were taken from the Ranvier microtome and sections were placed between two glass slides $(2 \times 4 \mathrm{~cm})$, frozen in liquid nitrogen, and then lyophilized (TERRONI-Model ENTERPRISE) for 12 hours. Once lyophilized, the cross-sections were placed on a $\mathrm{KBr}$ slide and the spectra recorded in an infrared VARIAN 640-IR FT-IR spectrometer equipped with a microscope. A liquid nitrogen-cooled Mercury Cadmium Telluride detector(MCT) was used and samples were run by diffuse reflectance, at a wave range of 700-4000 $\mathrm{cm}^{-1}$, spectral resolution of $2 \mathrm{~cm}^{-1}, 128$-scan and smoothing of 7 points. The spectra were registered from the epidermis to the vascular cylinder of stems and roots.

\section{Results and Discussion}

\subsection{Lignification status of root}

The adventitious root study of L. lactescens was performed in the distal and proximal regions (Figure 1a). The root, in a cross section, 1-4 cm from the root tip (distal region), indicates the primary structure initially formed by the epidermis with high cells, soon expanding to constitute the root hairs (Figure 1b, c). The cortex presents a layer of exodermis cells, well-developed and suberized at 3-4 cm from the apex. The parenchyma consists of seven layers of isodiametric cells, surrounded by small intercellular spaces which expand in volume in the proximal region from $12-17.5 \mathrm{~cm}$ and become lacuna (Figure 1d). In this area, certain cells adjacent to the exodermis undergo periclinal and anticlinal divisions. Endodermis cells only present Casparian strips in the root's length (Figure 1e, f). In the vascular cylinder, the pericycle is formed by a layer of parenchyma cells. The primary xylem varied the number of diarch, triarch and tetrarch poles (Figure 1c, e, g). In most eudicotyledonous species, the number of xylem poles varies among specimens, or in different roots of the same plant (Esau, 2000; Fahn, 1985). The number of protoxylem poles, according to Mauseth (1988), can be related to the root's strength and diameter. Occasionally, the more robust a single root in an advanced development stage is, the higher the number of xylem poles. According to Dickison (2000), this variation is influenced by the hormone levels found in the root tip.

The vascular cylinder is comprised of parenchyma cells, 3-4 cm from the apex, and completely lignified. Only in the proximal region are the xylem fibers lignified and thick, making them conspicuous (Figure 1h).

Metcalfe and Chalk (1950) already mentioned that this family demonstrated the presence of isolated or grouped calcium oxalate crystals and cells possessing tannins. In the distal region of L. lactescens, several idioblasts with phenolic compounds were observed in cortical cells (Figure 1i). In plants, tannins are designed to protect against decay and injuries caused by microorganisms (Fahn, 1985). However, despite the sterile environment, individuals still produced these compounds, indicating another physiological activity of the species.

Infrared spectra of roots showed lignin with guaiacyl/ syringyl composition. Donaldson (2001) also observed in angiosperms lignin contains a mixture of guaiacyl and syringyl units.

\subsection{Lignification status of young stems}

The cross-sections of the stems were extracted using ethanol and later analyzed by infrared microscopy. The spectrum emitted signals at 1636, 1507, 1336 and $1246 \mathrm{~cm}^{-1}$, demonstrating the occurrence of G/S lignin, had a higher guaiacyl unit content (Lin and Dence, 1992).

The signal at $1738 \mathrm{~cm}^{-1}$ is due to carbonyl stretching of esters/carboxylic acids, indicative of the presence of hemicelluloses in pre-extracted cells, as well as all internodes evaluated individually by infrared microscopy (Figure 3b).

In the cylindrical and rectilinear stems (Figure 2a) of specimens having normal development, from the $1^{\text {st }}$ to $3^{\text {rd }}$ internodes, in a cross-section, an uniseriate epidermis was observed, whose cells presented varied shapes and sizes and a convex external periclinal wall, covered with a thin cuticle (data not shown). The covering tissue presented unicellular tector trichomes and trichomes with two horizontal arms (dibrachial), suspended by a thick basal cell wall (Figure 2c, d). Metcalfe and Chalk (1950) reported the presence of such trichomes in Malpighia urens $L$.

The cortex, in the first internodes, presented 2-3 layers of angular collenchyma, 5-6 layers of parenchyma cells (Figure 2e), and the starch sheath (data not shown).

Lignification of pericyclic fibers was observed in the vascular cylinder, sourced from the first internodes. The conductive elements formed collateral beams, interrupted by parenchyma cells, featuring a discontinuous cylinder (Figure 2f). The phloem consists of small sieve-tube elements and their companion cells, and frequent presence of idioblasts with diverse contents. These mentioned features observed in L. lactescens corroborate with the descriptions made by Metcalfe and Chalk (1950) for various genera of the family.

Xylem, in the primary state of growth, presented radial fibers with 2-8 conducting elements. It was possible to monitor the lignification process of protoxylem and 

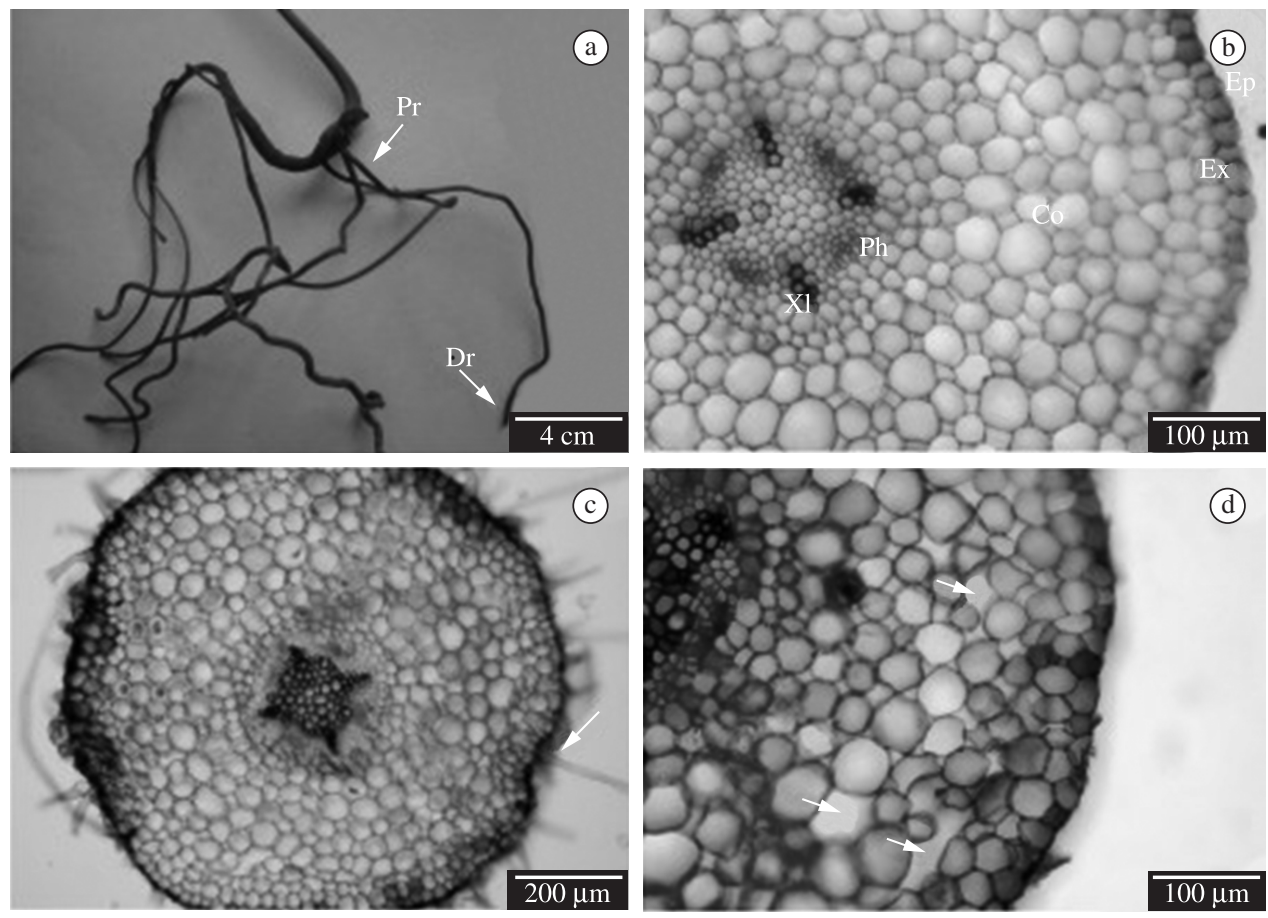

(d)
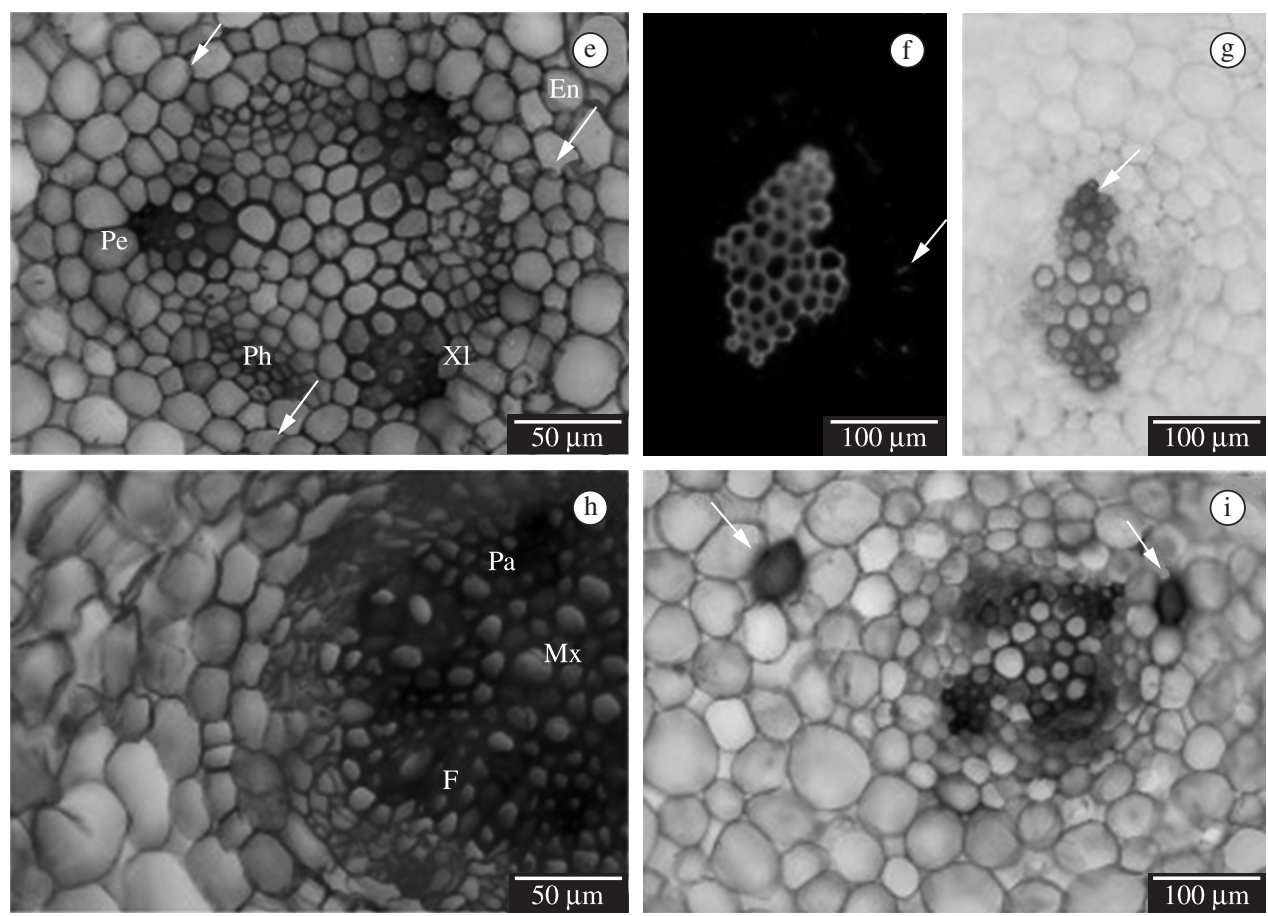

Figure 1. Adventitious root of Lophanthera lactensces grown in vitro. a) Detail of adventitious root. b) 1-Cross section; General aspect of the root $1-4 \mathrm{~cm}$ from the rood tip. c) General aspect, showing the root hairs $(\rightarrow)$ and the four xylem poles. d) General aspect of the root in the proximal region, with large intercellular spaces $(\rightarrow)$. e) Detail of the triarch root, remarking Casparian strips in endodermis $(\rightarrow)$. f) Detail of lignified diarchial root and suberified Casparian strips $(\rightarrow)$ shown by fluorescence microscopy. g) Detail of xylem lignification $(\rightarrow)$, shown by Wiesner's test. h) Detail of root in proximal region, showing parenchyma cells, fibers and metaxylem with thick and lignified walls $(\rightarrow)$. i) Detail of cortical area, showing the presence of phenolic substances in the parenchyma and in endodermis. $\operatorname{Pr}=$ Proximal region, $\mathrm{Dr}=\mathrm{Distal}$ region; Ep = Epidermis; Ex = Exodermis; $\mathrm{Co}=$ Cortex $\mathrm{Ph}=$ Phloem; Xl = Xylem; $\mathrm{Me}=$ Metaxylem; En = Endodermis; $\mathrm{Pa}=$ Parenchyma; $\mathrm{F}=$ Fibers. Bars $=\mathrm{C}=200 \mu \mathrm{m} . \mathrm{b}, \mathrm{d}, \mathrm{f}, \mathrm{g}, \mathrm{i}=100 \mu \mathrm{m}$. e, $\mathrm{h}=50 \mu \mathrm{m}$. 

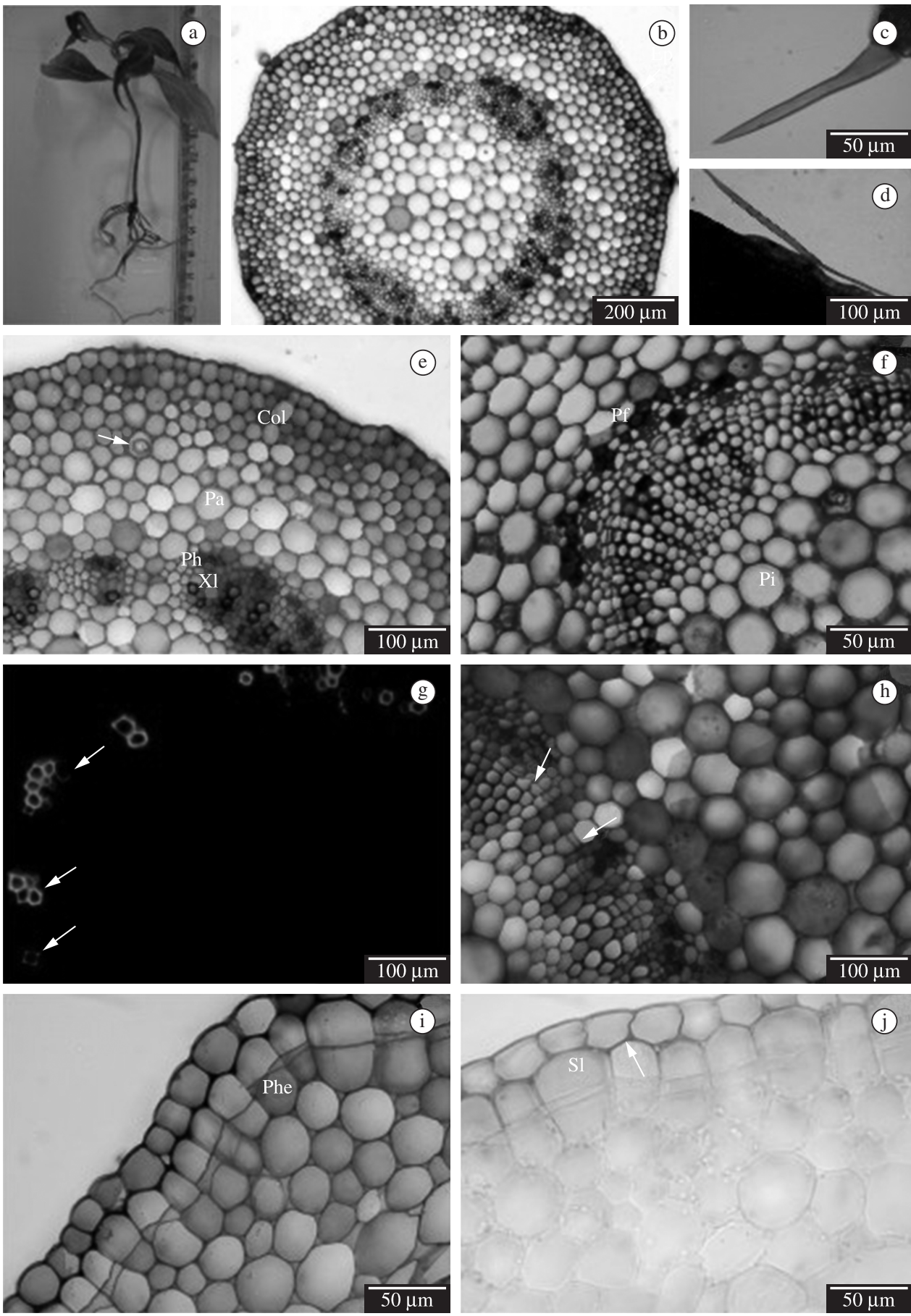

Figure 2. Lophanthera lactensces grown in vitro. a) Overview of individuals with rectilinear stem, at nine months. b, c, e-j) Cross section of stem. b) General aspect of stem in $2^{\text {nd }}$ internode. c) Detail of unicellular tector trichoma. d) Front view of dibrachial tector trichoma. e) General aspect of the cortex, showing angular collenchyma and idioblasts with druses $(\rightarrow)$. f) Detail of central cylinder, showing pericyclic fibers. g) Detail of the xylem lignification process with fluorescent microscopy. h) Detail of the central cylinder with initial fascicular cambial formation $(\rightarrow)$. i) Detail of phellogen differentiation. j) Detail of suberification $(\rightarrow)$. Ep = Epidermis; Col = Collenchyma; $\mathrm{Pa}=$ Parenchyma; $\mathrm{Ph}=$ Phloem; Xl $=$ xylem; Pf $=$ Pericyclic fiber; $\mathrm{Pi}=$ Pith; Phe = Phellogen; $\mathrm{Sl}=$ Subepidermal layer. Bars $=\mathrm{B}=200 \mu \mathrm{m} ; \mathrm{h}, \mathrm{g}, \mathrm{e}, \mathrm{d}=100 \mu \mathrm{m} ; \mathrm{c}, \mathrm{j}, \mathrm{i}, \mathrm{f}=50 \mu \mathrm{m}$. 
metaxylem elements using fluorescence microscopy. In L. lactescens, the lignin deposition began in cell corners, with a progressive deposit and completion in the secondary wall corroborating with Donaldson's account (2001) (Figure 2g). From the $4^{\text {th }}$ and $5^{\text {th }}$ internodes, the presence of one to two layers of cambial cells in the vascular cylinder was observed (Figure 2h). Concurrently, in the cortical region, there was a phellogen differentiation among the first sub epidermal layers by the thickening of the external periclinal wall, which extends to the anticlinal walls (Figure 2i). The suberification process was confirmed by the positive reaction with Sudan IV (Figure 2j). According to Metcalfe and Chalk (1950), early onset of the emergence of peridermis cells having thin walls may present a significant thickening in the tangential wall and, to a lesser extent, the side walls, as observed in the studied species. Infrared spectra of the peridermis region demonstrated characteristic signals of phenolic compounds and their presence was confirmed by histochemical tests.

At the $7^{\text {th }}$ and $8^{\text {th }}$ internodes, the xylem elements were fully differentiated, occupying the entire vascular cylinder, the cortical region was reduced and the peridermis poorly developed. In the cross-section, the secondary xylem of L. lactescens presented: solitary vessel elements having a circular to polygonal outline; reasonably thick-walled fibers and reduced lumen; and a uniseriate radial parenchyma. The thick, lignified walls were observed when running the Wiesner test and fluorescence microscopy (Figure 3c, d). The Maüle test confirmed the prevalence of syringyl lignin by the intense red color in cell walls. The syringyl lignin occurs predominantly in both fibers and ray cell walls while in the vessel walls there was a predominance of guaiacyl lignin (Musha and Goring, 1975). The signals at $1635,1507,1455,1336-1330$ and $1246 \mathrm{~cm}^{-1}$ obtained by infrared microscopy corroborated with the previous results in determining lignin (Figure 3a, b). The guaiacyl and syringyl lignin are questioned base on structural resistance as found in special tissue in trees, however in Lophanthera lactescens wood the original lignin compositions were characterized as guaiacyl/syringyl lignin, as well as in vitro (Abreu, 1997).

Certain studied specimens, given their accelerated development, presented stem sprains at all levels, resulting in structural modifications. From the $2^{\text {nd }}$ internode, a formation of gelatinous fibers in phloem and xylem was observed, occupying half of the vascular cylinder. These cells showed walls having a thick inner layer (G-layer), consisting of $\alpha$-cellulose with little to no lignin (Costa, 2006). From the $3^{\text {rd }}$ to the $7^{\text {th }}$ internodes, using the Wiesner test, the Maüle test and fluorescence microscopy, these wall features could be observed. These results are consistent with the hypothesis that the distinguished traction of tissues possesses lignin with high syringyl content. It is compatible with the molecular resistance hypothesis. Syringyl lignin in mutant plants demonstrated a more progressive increase of elastic module than guaiacyl lignin (Koehler and Telewski, 2006).
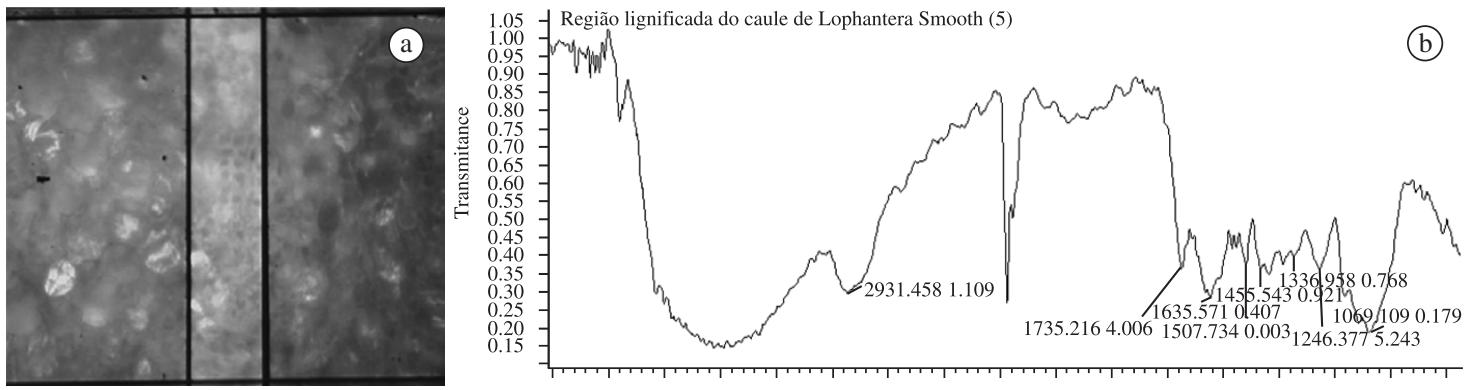

$\begin{array}{llllllllllllllll}3800 & 3600 & 3400 & 3200 & 3000 & 2800 & 2600 & 2400 & 2200 & 2000 & 1800 & 1600 & 1400 & 1200 & 1000 & 800\end{array}$ $\mathrm{cm}^{-1}$
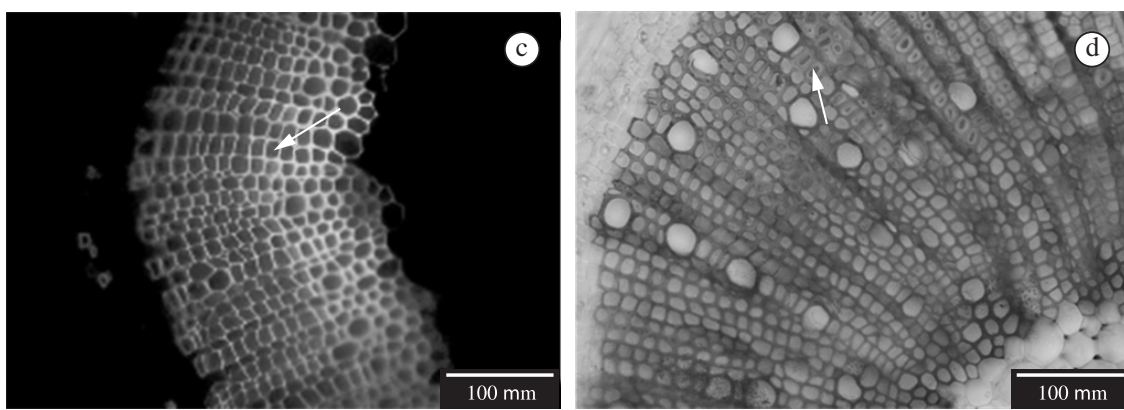

Figure 3. Organogram of infrared microscopy of L. lactescens grown in vitro. a) Detail of the xylem area in the $4^{\text {th }}$ internode, used in IV microscopy of the stem. b) Spectrum of L. lactescens recorded from the stem transversal section. c) Lignification of xylem cells visualized by fluorescence microscopy. d) Aspects of lignification of fibers walls, using the Maüle's tests. Bars: $\mathrm{c}, \mathrm{d}=100 \mu \mathrm{m}$. 
The increase in cambial activity in the middle of the vascular cylinder and the occurrence of gelatinous fibers in the twisted stems of L. lactescens appeared to be a survival strategy in response to in vitro growth environment or hormone activity (Kwon, 2008). However, Heimsch (apud Metcalfe and Chalk, 1950) cited the occurrence of gelatinous fibers in the wood of the Malpighiaceae species.

\section{Conclusion}

This study, the first of its kind concerning Lophanthera lactescens Ducke, proves that this specific species is a possible model in the study of lignification for woody plants, given the remarkable growth of secondary tissues in vitro. The infrared microscopy associated with fluorescence microscopy and the histochemical tests effectively identified lignin composition in the cell wall, proving that the lignification process in L. lactescens initiates in the cell corner and lignin contains high syringyl units of the secondary wall in the xylem of stems. Individuals under growth stress showed gelatinous fibers with a lack of lignin in the G-layer.

Acknowledgements - The authors would like to thank the Coordenação de Aperfeiçoamento de Pessoal de Nível Superior (CAPES), which granted a scholarship; the Fundação de Amparo à Pesquisa do Estado do Rio de Janeiro (FAPERJ), for financial support and the anonymous reviewers for their valuable comments.

\section{Reference}

ABREU, HS., 1997. Estimativa por infravermelho da concentração da unidade estrutural $\beta-\mathrm{O}-4 \mathrm{em}$ ligninas de angiospermas tropicais. Química Nova, vol. 20, no. 6, p. 592-598. http://dx.doi.org/10.1590/ S0100-40421997000600005

ABREU, HS., BRAZ, F., GOTTLIEB, HE. and SHOOLERY, JN., 1990. A nor - triterpenoid from Lophanthera lactescens. Phytochemistry, vol. 29, no.7, p. 2257-2261. http://dx.doi. org/10.1016/0031-9422(90)83048-6

ABREU, HS., LATORRACA, JV., PEREIRA, RPW., MONTEIRO, MBO., ABREU, FA. and AMPARADO, KFA., 2009. Supramolecular Proposal of Lignin in Structure And its Relation with the Wood Proprieties. Academia Brasileira de Ciência, vol. 81, no. 1, p. 202- 211.

BERLYN, GP. and MIKSCHE, JP., 1976. Botanical microtechnique and cytochemistry. Ames: Iowa State University. p. 121-276.

BROWNING, BL., 1967. Methods of wood chemistry. New York: Interscience Publishers. vol. 2, 800 p.

BUKATSCH, F., 1972. Bermerkungen zur Doppel färbung Astrablau-Safranin. Mikrokosmos. vol. 61, 255 p.

CHAMBERLAIN, CJ., 1932. Methods in plant histology. 5nd ed. The University of Chicago Press.

CORRÊA, M., 1926. Dicionário de plantas úteis do Brasil e das exóticas cultivadas. Rio de Janeiro: Imprensa Nacional. vol. 03.

COSTA, AS., 2006. Sustentabilidade da produção de alecrim pimenta (Lippiasidoides Cham.): Micropropagação visando à conservação in vitro. Recife: Universidade Federal de Sergipe. 70 p. Dissertação de Mestrado em Agroecossistemas.
DE MICCO, V. and ARONNE, G., 2007. Combined histochemistry and autofluorescence for identifying lignin distribution in cell walls. Biotechnology \& Histochemistry, vol. 82, p. 209-216. http://dx.doi.org/10.1080/10520290701713981

DICKISON, WC., 2000. Integrative Plant Anatomy. Harcourt Acad. Press. 533 p.

DONALDSON, LA., 2001. Lignification and lignin topochemistry - an ultrastructural view. Phytochemistry, vol. 57, p. $859-873$.

ESAU, K., 2000. Anatomia das plantas com sementes. 15th ed. São Paulo: Edgard Blucher, 293 p.

FAHN, A., 1985. Anatomia vegetal. 3rd ed. Madri: Ediciones Pirâmide S. A. 599 p.

GABE, M., 1968. Techniques Histologiques. Grinwich: Masson Cle. 230 p.

GERRITS, PO. and SMID, L., 1983. A new, less toxic polymerization system for the embedding of soft tissues in glycol methacrylate and subsequent preparing of serial sections. Journal of Microscopy, no. 132 , p. $81-85$.

GUIMARÃES, CS., LACORTE, C. and BRASILEIRO, ACM., 2003. Transformação genética em espécies florestais. Revista Ciência Florestal, vol. 13, no. 1, p. 167-178.

JENSEN, DH., 1962. Botanical Histochemistry - Principles and Practice. São Francisco: W, H. Freeman and Company. 408 p.

KWON, MI., 2008. Tension Wood as a Model System to Explore the Carbon Partitioning between Lignin and Cellulose Biosynthesis in Woody Plants, Journal of Applied Biological Chemistry, vol. 51, no. 3, p. 83-87. http://dx.doi.org/10.3839/jabc.2008.018

KOEHLER, L. and TELEWSKI, FW., 2006. Biomechanics and transgenic wood. Journal of Botany, vol. 93, no. 10, p. 14331438. PMid:21642090. http://dx.doi.org/10.3732/ajb.93.10.1433

LIN, SY. and DENCE, CW., 1992. Methods in lignin chemistry. Berlim: Spring-Verlag. 568 p.

LORENZI, H., 1992. Árvores brasileiras: manual de identificação e cultivo de plantas nativas do Brasil. Nova Odessa: Plantarum. vol. $1,352 \mathrm{p}$.

MARTONE, PT., ESTEVEZ, JM., LU, F., RUEL, K., DENNY, MW., SOMERVILLE, C. and RALPH J., 2009. Discovery of Lignin in Seaweed Reveals Convergent Evolution of Cell-Wall Architecture. Current Biology, vol. 19, p. 169-175. PMid:19167225. http://dx.doi.org/10.1016/j.cub.2008.12.031

MAUSETH, JD., 1988. Plant Anatomy. The Benjamim, Cummings publishing company. $560 \mathrm{p}$.

METCALFE, CR. and CHALK, L., 1950. Anatomy of the dicotyledons: leaves, stem and wood in relation to taxonomy with notes on economic uses. Oxord: Claredon Press. vol. 2.

MONTIES, B., 1989. Molecular structure and biochemical properties of lignins in relation with possible self-organization of lignin network. Annales des Siences Forestières, vol. 46, p. 846-855. http://dx.doi.org/10.1051/forest:198905ART0187

MORAIS, SAL., NASCIMENTO, EA. and MELO, DC., 2005. Chemical analysis of the Pinus oocarpa wood. Part II - characterization of the milled wood lignin. Revista Árvore, vol. 29 , no. 3 .

MURASHIGE, T. and SKOOG, F., 1962. A revised medium for rapid growth and bioassays with tobacco tissue cultures. 
Physiologia Plantarum, vol. 15, p. 473-497. http://dx.doi. org/10.1111/j.1399-3054.1962.tb08052.x

MUSHA, Y. and GORING, DAI., 1975. Distribution of Syringyl and Guaiacyl moieties in hardwoods as indicated by ultraviolet microscopy. Wood Science and Technology, vol. 9, p. 45-58. http://dx.doi.org/10.1007/BF00351914

O'BRIEN, TP. and MCCULLY, ME., 1981. The study of plant structure: Principles and selected methods. Melbourne: Termarcarphi Pty Ltd.

PAOLI, AAS., 1997. Morfo-anatomia de frutos e sementes de Lophantera lactescens Ducke (Malpighiaceae). Revista Brasileira de Sementes, vol. 19, no. 2, p. 237-243.
SALIBA, EOS., RODRIGUES, MN., MORAIS, SAL. and PILÓ-VELOSO, D., 2001. Ligninas - Métodos de obtenção e caracterização química. Ciência Rural, vol. 31, no. 5, p. 917-928.

SOUZA, KCA. and ABREU, HS., 2007. Biotecnologia aplicada ao estudo da lignificação. Revista Floresta e Ambiente, vol. 14, no. 1, p. 93-109.

TERASHIMA, N. and FUKUSHIMA, K., 1988. Heterogeneity in formation of lignin. An autoradiographic study of the heterogeneous formation and structure of pine lignin. Wood Science Technology, vol. 22, p. 259-270. http://dx.doi.org/10.1007/BF00386021

TREVISAN, H., 2003. Ocorrência de térmitas subterrâneos (Isoptera: Rhinotermitidae e Termitidae) e durabilidade natural da madeira de cinco essências florestais. Revista Ciência Florestal, vol. 13 , no. 2 , p. $153-158$. 